\title{
The Harris-Todaro Hypothesis
}

\author{
M. Ali Khan
}




\title{
PIDE Working Papers
}

2007:16

\section{The Harris-Todaro Hypothesis}

\author{
M. Ali Khan \\ Abram Hutzler Professor of Economics \\ The Johns Hopkins University, Baltimore, USA
}

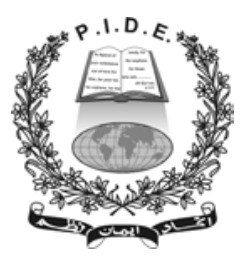

PAKISTAN INSTITUTE OF DEVELOPMENT ECONOMICS ISLAMABAD 
All rights reserved. No part of this publication may be reproduced, stored in a retrieval system or transmitted in any form or by any means-electronic, mechanical, photocopying, recording or otherwise-without prior permission of the author(s) and or the Pakistan Institute of Development Economics, P. O. Box 1091, Islamabad 44000.

\section{(C) Pakistan Institute of Development}

Economics, 2007.

Pakistan Institute of Development Economics

Islamabad, Pakistan

E-mail: publications@pide.org.pk

Website: http://www.pide.org.pk

Fax: $\quad+92-51-9210886$

Designed, composed, and finished at the Publications Division, PIDE. 


\begin{abstract}
The Harris-Todaro hypothesis replaces the equality of wages by the equality of 'expected' wages as the basic equilibrium condition in a segmented but homogeneous labour market, and in so doing it generates an equilibrium level of urban unemployment when a mechanism for the determination of urban wages is specified. This article reviews work in which the Harris-Todaro hypothesis is embedded in canonical models of trade theory in order to investigate a variety of issues in development economics. These include the desirability (or the lack thereof) of foreign investment, the complications of an informal sector, and the presence of clearly identifiable ethnic groups.
\end{abstract}

JEL classification: J3

Keywords: Harris-Todaro, Wages, Labour Economics, Labour Market, Rural to Urban Migration 

The Harris-Todaro hypothesis replaces the equality of wages by the equality of 'expected' wages as the basic equilibrium condition in a segmented, but homogeneous, labour market, and in so doing, generates an equilibrium level of urban unemployment when a mechanism for the determination of urban wages is specified. This entry reviews work in which the Harris-Todaro hypothesis is embedded in canonical models of trade theory in order to investigate a variety of issues in development economics. These include the desirability (or the lack thereof) of foreign investment, the complications of an informal sector and the presence of clearly-identifiable ethnic groups.

The replacement of the equality of wages by the equality of 'expected' wages as the basic equilibrium condition in a segmented, but homogeneous, labour market has proved to be an idea of seminal importance in development economics. Attributed originally to Todaro (1968, 1969) and Harris-Todaro (1970), and commonly referred to as the Harris- Todaro hypothesis, the idea was very much in the air around the late 1960s as can be seen from the contemporaneous writings of Akerlof-Stiglitz (1969), Blaug, et al. (1969) and Harberger (1971), among others.

The motivation for the Harris-Todaro hypothesis lies in an attempt to explain the persistence of rural to urban migration in the presence of widespread urban unemployment, a pervasive phenomenon in many, so-called less developed, countries [but also see Suits (1985) and Partridge-Rickman (1987)]. It is natural to ask why such unemployment does not act as a deterrent to further migration. According to the HarrisTodaro hypothesis, the answer lies in the migrant leaving a secure rural wage $w_{r}$ for a higher expected urban wage $w_{u}^{e}$ even though the latter carries with it a non-zero probability of urban unemployment. The expected wage is computed by using the rate of urban employment as an index for the probability of finding a job. Thus

$$
w_{u}^{e}=w_{u} \frac{L_{u}}{L_{u}+U}+0 \frac{U}{L_{u}+U}=w_{u} \frac{1}{1+\lambda}, \quad \ldots \quad \ldots
$$

where $w_{u}$ is the urban wage, $L_{u}$ is the number of urban employed, $U$ the number of urban unemployed and $\lambda=\left(U / L_{u}\right)$ the rate of urban unemployment. Thus, the HarrisTodaro hypothesis is precisely formulated by the equilibrium condition

$$
w_{r}=w_{u}^{e} \Leftrightarrow w_{u}=w_{r}(1+\lambda) \quad \ldots \quad \ldots \quad \ldots \quad \ldots \quad \ldots
$$

Since the Harris-Todaro hypothesis introduces a further unknown, namely the rate of unemployment, a model in which the hypothesis is embedded must be buttressed by a theory of urban wage determination. The simplest setting is the one originally adopted by Harris-Todaro and subsequently by Bhagwati-Srinivasan (1971, 1973, 1974). This setting assumes the urban wage to be an exogenously given constant

Author's Note: A version of the above text will appear in a new, forthcoming edition (2007) of The New Palgrave: A Dictionary of Economics. 
and typically rationalizes it as a consequence of government fiat.

In the 1970s, however, several theories of endogenous urban wage determination were simultaneously proposed. Foremost among these is the work of Stiglitz who provides a microfoundation for the urban wage in terms of labourturnover [Stiglitz (1974)], or in terms of biological efficiency considerations [Stiglitz (1976)]. One may also mention in this context the work of Calvo (1978), who sees the equilibrium urban wage as an outcome of trade union behaviour [also Quibria (1988) and Chau-Khan (2001)]; and of Calvo-Wellisz (1978), who see a higher urban wage as a consequence of costly supervision. At this stage of the development of the literature, each theory of urban wage determination led to a particular version of the Harris-Todaro model and the common structural similarities were obscured.

In Khan (1980a), the elementary observation is made that all these variants of the Harris-Todaro model could be studied under one rubric if the Harris-Todaro hypothesis is embedded in the Heckscher-Ohlin-Samuelson (HOS) two-sector, socalled general equilibrium model [see Jones (1965) or Johnson (1971)], and the determination of urban wages is seen in a somewhat more abstract way, i.e.,

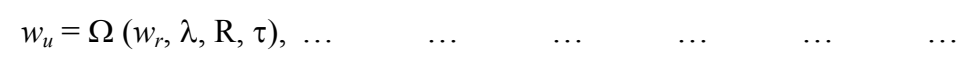

where $R$ is the rental on capital and $\tau$ a shift parameter. This led to a model whose importance lay not so much in synthesising the several variants of urban wage determination, but in emphasising the points of contact with the trade theory literature. In particular, when (3) collapses to

$$
\begin{array}{lllllllll}
w_{u}=w_{r}, & \ldots & \ldots & \ldots & \ldots & \ldots & \ldots & \ldots
\end{array}
$$

that is, when the elasticity of the omega function $\Omega(\cdot)$ with respect to $w_{r}$ is unity, and those with respect to $R$ and $\lambda$ are zero, we obtain the HOS model.

This point deserves further articulation. Let a stylised economy consist solely of an urban and a rural sector, indexed by $u$ and $r$ respectively, and be endowed with positive amounts of labour $L$ and capital $K$. Let the $i$ th sector produce a commodity $i$ in amount $X_{i}$ in accordance with a production function

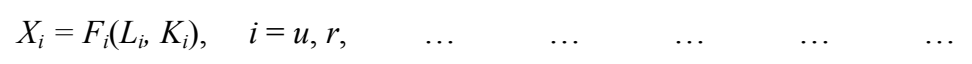

which is assumed to exhibit constant returns to scale and is twice continuously differentiable and concave. The allocation of labour and capital, $L_{i}$ and $K_{i}$, is determined through marginal productivity pricing. Thus, we have

$$
p_{r} F_{r}^{K}=R=p_{u} F_{u}^{K}, p_{r} F_{r}^{L}=w_{r} \text { and } p_{u} F_{u}^{L}=w_{u}, \quad \ldots \quad \ldots
$$

where $F_{i}^{j}$ is the derivative of $F_{i}(i=u, r)$ with respect to $j\left(j=L_{i}, K_{i}\right)$. The economy is considered too small to influence the positive international prices of the two commodities, $p_{u}$ and $p_{r}$. On rewriting the equilibrium condition (2) in the slightly more general form,

$$
\begin{array}{lllll}
w_{u}=\rho w_{r}(1+\lambda) ; \rho \text { a shift parameter, } & \ldots & \ldots & \ldots & \ldots
\end{array}
$$


(3), (5), (6) and (7), along with the material balance equations below, complete the specification of the model.

$$
K_{r}+K_{u}=K \text { and } L_{r}+L_{u}(1+\lambda)=L . \quad \ldots \quad \ldots \quad \ldots \quad \ldots
$$

The first point to be noticed about this model is a decomposability property whereby the factor prices, $w_{u}, w_{r}, R$ and the unemployment rate $\lambda$ are all independent of the endowments of labour and capital and depend solely on $p_{u}, p_{r}$ and the shift parameters $\tau$ and $\rho$. This can be seen most easily if we subsume the marginal productivity conditions (6) into price-equal-unit-cost equations

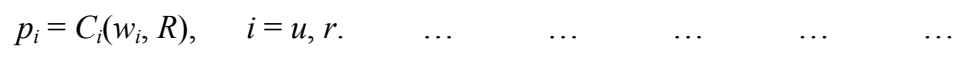

This allows one to decompose the model into a subsystem comprising Equations (7) and (3) along with (9). This basic observation leads to several interesting characteristics of the equilibria of the model. First, the market rural wage and market rental correctly measure the social opportunity cost of labour and capital if we use the international value of GNP as the relevant measure of social welfare. Second, despite the presence of a distorted labour market, there is no possibility of immiserising growth. Third, an increase in capital (labour) increases the output of the capital (labour) intensive commodity provided of the labour (capital) intensive commodity provided the intensities are measured in employment adjusted terms, that is

$$
\frac{k_{u}}{1+\lambda}=\frac{K_{u}}{L_{u}(1+\lambda)}>(\text { or }<) \frac{K_{r}}{L_{r}}=k_{r} . \quad \ldots \quad \ldots \quad \ldots
$$

This third property is an analogue of the Rybczynski property of the HOS model. Not surprisingly, we also obtain an analogue of the Stolper-Samuelson property whereby the effect of changes in international prices on factor returns depends on factor intensities, provided these are now measured in elasticity adjusted terms. The urban sector is said to be capital intensive in elasticity adjusted terms if

$$
\theta_{r} L\left(\theta_{u} K(1-e \lambda)+\theta_{u} L e R\right)-\theta_{u} L \theta_{r} K\left(e_{w}-e \lambda\right)>\text { or }<0, \quad \ldots \quad \ldots
$$

where $\theta_{i j}$ is the share of the $j$ th factor $(j=K, L)$ in the $i$ th sector $(i=u, r)$, and $e_{i}$ is the elasticity of the $\Omega(\cdot)$ function with respect to the relevant variable. In the setting where $e_{w}$ equals unity and $e_{R}$ and $e \lambda$ are all zero, (10) and (11) collapse to the conventional physical and value intensities of Magee (1976) and Jones (1971) for the HOS model with proportional wage differentials. Under the further specialisation that $\rho$ in (7) equals unity, there is no difference between these two kinds of intensities and a perfect correspondence between the Rybczynski and StolperSamuelson theorems.

This re-appearance of the divergence of the physical and value intensities of the wage-differential model leads us to inquire into the possibility of downwardsloping supply curves of $X_{r}$ and $X_{u}$. This is indeed a possibility and a sharp generalisation is available in the result that there are perverse price-output responses 
in the model if and only if the employment adjusted factor intensities do not conflict with the elasticity adjusted intensities; see Khan (1980b) for details. Another direct consequence of the decomposability property of the model is a generalisation of the Bhagwati (1968), Johnson (1971), Brecher-Alejandro (1977) paradox. This states that capital inflow in the presence of a tariff and with full repatriation of its earnings is immiserizing if and only if the imported commodity is capital intensive in employment adjusted terms. This result is independent of the various mechanisms for the determination of urban wages; see Khan (1982a) for details, and also subsequent work by Beladi-Naqvi (1988), Grinols (1991), Chao-Yu (1994, 1995c), Chaudhuri-Mukhupadhyay (2002), Chaudhuri (2003a) and Sen, et al. (1997). Both of these results have a trade-theoretic flavour, and one question that has remained in the forefront of analytical work on the Harris-Todaro hypothesis relates to the effect of urban wage subsidies on urban unemployment and urban output. (As emphasized above, this question could indeed be seen as the raison d'etre for the introduction of the hypothesis.) A seminal result here is the Corden-Findlay (1975) paradox which draws attention to the fact that urban employment and urban output could rise if the urban wage is increased. This question has been readdressed by Neary (1981) and completely resolved in the context of endogenous urban wage determination by Khan (1980b).

So far we have focused on the comparative-static properties of the HarrisTodaro equilibrium. It is also worth emphasizing that the actual existence of the Harris-Todaro equilibrium cannot be taken for granted and must be proved. In the original Harris-Todaro model with an exogenously given rigid wage, equilibrium exists if and only if the rural sector is more capital intensive in employment adjusted terms; see Khan (1980a) and Basu (1991) for an application of the geometric technique. Furthermore, once the 'isomorphism' with the HOS model is established and understood, one can follow Neary's (1978) lead and ask for 'reasonable' adjustment processes under which the Harris-Todaro equilibrium is locally asymptotically stable. It can be shown that an adjustment process of the Marshallian type leads to a stable equilibrium if and only if the employment adjusted factor intensities do not conflict with the elasticity adjusted intensities; see Khan (1980b) for details. Since the elasticity adjusted intensities of (11) collapse to $\theta_{r} L \theta_{u} K$ in the Harris-Todaro model with a rigid wage, we have the satisfying result that the criteria for the existence of equilibrium and its stability coincide; also see Neary (1981) for this special case.

The 1987 Palgrave entry on this subject was furnished under the title HarrisTodaro model, and the model presented above referred to as the 'generalized HarrisTodaro' (GHT) model. This is somewhat misleading in that any model in which the Harris-Todaro hypothesis is embedded has a justifiable claim to the title of a HarrisTodaro model. Indeed, unlike the case of the HOS model where capital is intersectorally mobile, the hypothesis can be embedded in the Ricardo-Viner model, a setting with three factors, or under an alternative interpretation, one where capital can be viewed as non-shiftable (for details on this and other basic constructions of classical trade theory, [see, for example, Caves-Jones (1985)]. In many ways, this 
case of a two sector model with sector-specific capital is more difficult and also more interesting; see Khan (1982) and Bhatia (2002) for details. And there is at least one example in the literature where a particular Harris-Todaro model has been exported to international trade theory rather than imported from it: Jones-Marjit (1992) investigate a multi-sectoral setting of Khan (1991) by stripping it of the Harris-Todaro hypothesis.

This updated entry would be seriously incomplete if it did not note a criticism of the Harris-Todaro hypothesis centering on the urban unemployed living on a zero wage, and a corresponding generalisation of the hypothesis. This criticism also dovetails into an issue that has received increasing attention from sociologists and development economists in the last fifteen years: the existence of a dynamic informal urban sector, and the possibility of the urban unemployed being incorporated in it; see Portes (1989) and Fields (1975, 2005b) and their references. This has led to a reformulation of (1) and (2) to

$$
\begin{aligned}
& w_{u}^{e}=w_{u} \frac{L_{u}}{L_{u}+U}+w_{i} \frac{U}{L_{u}+U}=\frac{w_{u}+\lambda w_{i}}{1+\lambda} \Rightarrow w_{r}=w_{u}^{e} \Leftrightarrow \\
& \begin{array}{llllll}
w_{u}+\lambda w_{i}=w_{r}(1+\lambda), \ldots & \ldots & \ldots & \ldots & \ldots
\end{array}
\end{aligned}
$$

where $w_{i}$ is the wage in the informal sector. Again, as in the original Harris-Todaro hypothesis, this generalised hypothesis can be embedded in alternative production structures to yield a variety of models tailored to the purpose the investigator has in mind; see Chandra (1991) and Chandra-Khan (1993) for a more detailed elaboration of this point of view. The subject continues to receive attention; see Stiglitz (1982), Fields (1990, 1997, 2005), Rauch (1991), Gupta (1993, 1997), Bandyopadhyay-Gupta (1995), Kar-Marjit (2001), Yabuuchi, et al. (2001, 2005) and Chaudhuri (2003b).

We conclude this entry with a partial list of some other issues in trade and development that have been discussed in the context of urban-rural migration: gains from trade, now depending on the asymmetric nature of the model and on whether the rural or the urban commodity is being exported, as in Khan-Lin (1982), Chao-Yu (1993, 1997, 1999) and Choi-Yu (2006); underemployment or educated unemployment as in Bhagwati-Srinivasan (1977) or in Chaudhuri-Khan (1984) and Chaudhuri-Mukhupadhyay (2003); public inputs as in Chao-Lafargue-Yu (2006); variable returns to scale as in Panagariya-Succar (1986), Beladi (1988) and Choi (1999); growth and technical progress as in Bourguignion (1990), Choi-Yu (1993, 1995a) and Chow-Zeng (2001); foreign enclaves as in Gupta-Gupta (1998); capital markets, distorted or otherwise, as in Khan-Naqvi (1983) and Chao-Yu (1992); interaction of ethnic groups as in Khan $(1979,1991)$ and Khan-Chaudhuri (1985); risk and uncertainty as in Beladi-Ingene (1994); environmental issues, as in ChaoKerkviliet-Yu (2000) and Chao-Yu (2003); cost-benefit analyses as in SrinivasanBhagwati (1975), Stiglitz (1977, 1982), Gupta (1988) and Chao-Yu (1995b); poverty and income inequality as in Moene (1992) and Rauch (1993). In summary then, the Harris-Todaro hypothesis is a versatile and useful analytic instrument for investigating a variety of questions arising in international and development economics where urban unemployment is a prominent issue. 


\section{REFERENCES}

Agesa, R. (2000) The Incentive for Rural to Urban Migration: A Re-examination of the Harris-Todaro Model. Applied Economics Letters 7, 107-110.

Akerlof, G., and J. E. Stiglitz (1969) Capital, Wages and Structural Employment. Economic Journal 79, 269-81.

Bandyopadhyay, M., and M. R. Gupta (1995) Development Policies in the Presence of an Informal Sector: A Note. Journal of Economics 61, 301-315.

Basu, A. (1991) Locational Choice for Free Trade Zones: A Comment. Journal of Development Economics 50, 381-387.

Beladi, H. (1988) Variable Returns to Scale, Urban Unemployment and Welfare. Southern Economic Journal 55, 412-423.

Beladi, H., and N. Naqvi (1988) Urban Unemployment and Non-immiserizing Growth. Journal of Development Economics 28, 365-376.

Beladi, H., and C. A. Ingene (1994) A General Equilibrium Analysis of Rural-Urban Migration under Uncertainty. Journal of Regional Science 34, 91-103.

Bhagwati, J. N. (1968) Distortions and Immiserizing Growth. Rewiew of Economics Studies 35, 481-5.

Bhagwati, J. N., and T. N. Srinivasan (1971) The Theory of Wage Differentials: Production Response and Factor Price Equalization. Journal of International Economics I, 19-35.

Bhagwati, J. N., and T. N. Srinivasan (1973) The Ranking of Policy Interventions under Factor Market Imperfections: The Case of Sector-specific Sticky Wages and Unemployment. Sankhya, Series B, 35(4), December, 405-20.

Bhagwati, J. N., and T. N. Srinivasan (1974) On Reanalyzing the Harris-Todaro Model: Policy Rankings in the Case of Sector-specific Sticky Wages. American Economic Review 64, 502-8.

Bhagwati, J. N., and T. N. Srinivasan (1977) Education in a Job Ladder Model and the Fairness-in-hiring Rule. Journal of Public Economics 7(1), 1-22.

Bhatia, K. (2002) Specific and Mobile Capital, Migration and Unemployment in a Harris-Todaro Model. Journal of International Trade and Economic Development 11, 207-222.

Blaug, M., P. R. G. Layard, and M. Woodhall (1969) The Causes of Graduate Unemployment in India. London: Allen Lane.

Bourguignion, F. (1990) Growth and Inequality in a Dual Model of Development: The Role of Demand Factors. Review of Economic Studies 64, 502-508.

Brecher, R. A., and C. F. Diaz-Alejandro (1977) Tarrifs, Foreign Capital and Immiserizing Growth. Journal of International Economics 7, 317-22.

Calvo, G. A. (1978) Urban Unemployment and Wage Determination in LDC's: Trade Unions in the Harris-Todaro Model. International Economic Review 19, 65-81.

Calvo, G. A., and S. Wellisz (1978) Supervision, Loss of Control and the Optimum Size of the Firm. Journal of Political Economy 86, 943-52.

Caves, R. E., and R. W. Jones (1985) World Trade and Payments. (4th Edn). Boston: Little, Brown \& Co. 
Chakravarty, S. R., and B. Dutta (1990) Migration and Welfare. European Journal of Political Economy 6, 119-138.

Chandra, V. (1991) The Informal Sector in Developing Countries: A Theoretical Analysis.. The Johns Hopkins University, Baltimore. Unpublished PhD dissertation.

Chandra, V. and M. Ali Khan (1993) Foreign Investment in the Presence of an Informal Sector. Economica 60, 79-103.

Chao, C. C., and E. S. H. Yu (1990) Urban Unemployment, Terms of Trade and Welfare. Southern Economic Journal 56, 743-751.

Chao, C. C., and E. S. H. Yu (1992) Capital Markets, Urban Unemployment and Land. Journal of Development Economics 38, 407-413.

Chao, C. C., and E. S. H. Yu (1993) Content Protection, Urban Unemployment and Welfare. Canadian Journal of Economics 26, 481-492.

Chao, C. C., and E. S. H. Yu (1994) Foreign Capital Inflows and Welfare in an Economy with Imperfect Competition. Journal of Development Economics 45, $141-154$.

Chao, C. C., and E. S. H. Yu (1995a) Urban Growth, Externality and Welfare. Regional Science and Urban Economics 24, 565-576.

Chao, C. C., and E. S. H. Yu (1995b) The Shadow Price of Foreign Exchange in a Dual Economy. Journal of Development Economics 46, 195-202.

Chao, C. C., and E. S. H. Yu (1995c) International Capital Mobility, Urban Unemployment and Welfare. Southern Economic Journal 61, 486-492.

Chao, C. C., and E. S. H. Yu (1997) Trade Liberalization in Oligopolistic Competition with Unemployment: A General Equilibrium Analysis. Canadian Journal of Economics 30, 479-496.

Chao, C. C., and E. S. H. Yu (1999) Export Promotion, Unemployment and National Welfare. International Economic Journal 13, 17-34.

Chao, C. C., and E. S. H. Yu (2003) Jobs, Production Linkages and the Environment. Export Promotion, Unemployment and National Welfare. Journal of Economics 79, 113-122.

Chao, C. C., J. Kerkviliet, and E. S. H. Yu (2000) Environmental Preservation, Sectoral Unemployment, and Trade in Resources. Review of Development Economics 4, 39-50.

Chao, C. C., J. Lafargue, and E. S. H. Yu (2006) Public Inputs, Urban Unemployment and Welfare in a Developing Economy. City University of Hong Kong. (Mimeo.)

Chau, N. H., and M. Ali Khan (2001) Optimal Urban Employment Policies: Notes on Calvo and Quibria. International Economic Review 42, 557-568.

Chaudhuri, S., and U. Mukhopadhyay (2002) Removal of Protectionism, Foreign Investment and Welfare in a Model of the Informal Sector. Japan and the World Economy.

Chaudhuri, S. (2001) Foreign Capital Inflow, Non-traded Intermediary, Urban Unemployment, and Welfare in a Small Open Economy. The Pakistan Development Review 40, 225-235. 
Chaudhuri, S. (2003) How and How far to Liberalize a Developing Economy with Informal Sector and Factor Market Distortions. Journal of International Trade and Economic Development 12, 403-428.

Chaudhuri, S., and U. Mukhopadhyay (2003) Free Education Policy and Trade Liberalization: Consequences on Child and Adult Labour Markets in a Small Open Economy. Journal of Economic Integration 18, 336-359.

Chaudhuri, T. D., and M. Ali Khan (1984) Educated Unemployment, Educational Subsidies and Growth. The Pakistan Development Review 23, 395-409.

Choi, J. (1999) Factor Growth, Urban Unemployment and Welfare Under Variable Returns to Scale. International Economic Journal 14, 17-34.

Choi, J., and E. S. H. Yu (1993) Technical Progress, Terms of Trade and Welfare in a Mobile Capital Harris-Todaro Model. In W. Neuefeind and R. Reizman (eds.) Economic Theory and International Trade: Essays in Memoriam of J. Trout Rader. New York: Springer-Verlag.

Choi, J. and E. S. H. Yu (2006) Industrial Targeting and Non-shiftable Capital in the Harris-Todaro Model. Review of International Economics 14, 1-12.

Chow, Y., and J. Zeng (2001) Foreign Capital in a Neoclassical Model of Growth. Applied Economics Letters 8, 613-615.

Corden, W. M., and R. Findlay (1975) Urban Unemployment, Intersectional Capital Mobility and Development Policy. Economica 42, 59-78.

Feldmann, D. H. (1989) The Trade-off between GNP and Unemployment in a Dual Economy. Southern Economic Journal 56, 46-55.

Fields, G. S. (1975) Rural-urban Migration, Urban Unemployment and Job-search Activity in LDCs. Journal of Development Economics 2, 165-87.

Fields, G. S. (1989) On-the-job Search in a Labour Market Model: Ex-ante Choices and Ex-post Outcomes. Journal of Development Economics 30, 159-178.

Fields, G. S. (1990) Labour Market Modelling and the Urban Informal Sector: Theory and Evidence. In D. Turnham (ed.) The Informal Sector and Evidence Revisited. Paris: OECD.

Fields, G. S. (1997) Wage Floors and Unemployment: A Two-sector Analysis. Labour Economics 4, 85-92.

Fields, G. S. (2005a) A Welfare Economic Analysis of Labour Market Policies in the Harris-Todaro Model. Journal of Development Economics 76, 127-146.

Fields, G. S. (2005b) A Guide to Multisector Labor Market Models. World Bank.

Grinols, E. L. (1991) Unemployment and Foreign Capital: the Relative Opportunity Costs of Domestic Labour and Welfare. Economica 62, 59-78.

Grossman, G. M. (1983) Partially Mobile Capital: A General Approach to Two Sector Trade Theory. Journal of International Economics 1-17.

Gupta, M. R. (1988) Migration, Welfare, Inequality and the Shadow-wage. Oxford Economic Papers 40, 477-486.

Gupta, M. R. (1993) Rural-urban Migration, Informal Sector and Development Policies: A Theoretical Analysis. Journal of Development Economics 41, 137151.

Gupta, M. R. (1995) Tax on Foreign Capital Income and Wage Subsidy to the Urban Sector in the Harris-Todaro Model. Journal of Development Economics 47, 469-479. 
Gupta, M. R. (1997a) Foreign Capital and the Informal Sector: comments on Chandra and Khan Economica 64, 353-363.

Gupta, M. R. (1997b) Informal Sector and Informal Capital Market in a Small Open Less-developed Economy. Journal of Development Economics 52, 409-428.

Gupta, K., and M. R. Gupta (1998) Foreign Enclaves and Economic Development: A Theoretical Analysis. Journal of Economics 67, 317-336.

Harberger, A. C. (1971) On Measuring the Social Opportunity Cost of labour. International Labour Review 103, 559-79.

Harris, J. R., and M. Todaro (1970) Migration, Unemployment and Development: A Two Sector Analysis. American Economic Review 40, 126-42.

Jha, R., and J. R. Whalley (2003) Migration and Unemployment, NBER paper.

Johnson, H. G. (1971) The Two-Sector Model of General Equilibrium. Yrj Jahnsson Lectures, Chicago: Aldine-Atherton.

Jones, R. W. (1965) The Structure of Simple General Equilibrium Models. Journal of Political Economy 73, 557-572.

Jones, R. W. (1971) Distortions in Factor Markets and the General Equilibrium Model of Production. Journal of Political Economy 79, 437-59.

Jones, R. W., and S. Marjit (1992) International Trade and Endogenous Production Structures. In W. Neuefeind and R. Reizman (eds.) Economic Theory and International Trade: Essays in Memoriam of J. Trout Rader New York: Springer-Verlag.

Kar, S., and S. Marjit (2001) Informal Sector in General Equilibrium: Welfare Effects of Trade Policy Reforms. International Review of Economics and Finance 10, 289-300.

Khan, M. Ali. (1979) A Multisectoral Model of a Small Open Economy with Nonshiftable Capital and Imperfect Labour Mobility. Economic Letters 2, 369-75.

Khan, M. Ali (1980a) The Harris-Todaro Hypothesis and the Heckscher-OhlinSamuelson Trade Model: A Synthesis. Journal of International Economics 10, 527-47.

Khan, M. Ali. (1980b) Dynamic Stability, Wage Subsidies and the Generalised Harris-Todaro Model. The Pakistan Development Review 19, 1-24.

Khan, M. Ali (1982a) Social Opportunity Costs and Immiserizing Growth: Some Observations on the Long Run Returns Versus and Short. Quarterly Journal of Economics 96, 353-62.

Khan, M. Ali (1982b) Tariffs, Foreign Capital and Immiserizing Growth with Urban Unemployment and Specific Factors of Production. Journal of Development Economics 10, 245-56.

Khan, M. Ali, and T. D. Chaudhuri (1985) Development Policies in LDCs with Several Ethnic Groups-A Theoretical Analysis. Zeitschrift fr Nationalkonomie 45, 1-19.

Khan, M. Ali, and P. Lin (1982) Sub-optimal Tariff Policy and Gains from Trade with Urban Unemployment. The Pakistan Development Review 21, 105-26.

Khan, M. Ali, and S. N. H. Naqvi (1983) Capital Markets and Urban Unemployment. Journal of International Economics 15 (3-4), 367-85. 
Khan, M. Ali (1991) Ethnic Groups and the Heckscher-Ohlin-Samuelson Trade Model. Economic Theory 1, 355-371.

Khan, M. Ali (1992). On Measuring the Social Opportunity Cost of Labour in the Presence of Tariffs and an Informal Sector. The Pakistan Development Review $31,535-562$.

Khan, M. Ali (1993) Trade and Development in the Presence of an Informal Sector: A Four Factor Model. In K. Basu, M. Majumdar, and T. Mitra (eds.) Capital Investment and Development. Oxford: Basil-Blackwell.

Magee, S. P. (1976) International Trade and Distortions in Factor Markets. New York and Basle: Marcel- Dekker.

Marjit, S. (1991) Agro-based Industry and Rural-urban Migration: A Case for an Urban Employment Subsidy. Journal of Development Economics 35, 393- 98.

Marjit, S. (2003) Economic Reform and Informal Wage-A General Equilibrium Analysis. Journal of Development Economics 72, 371-378.

Marjit, S., and H. Beladi (2003) Possibility or Impossibility of Paradoxes in the Small Country Harris-Todaro Framework. Journal of Development Economics $72,379-385$.

Moene, K. O. (1988) A Reformulation of the Harris-Todaro Mechanism with Endogenous Wages. Economics Letters 27, 387-390.

Moene, K. O. (1992) Poverty and Land Ownership. American Economic Review 82, $52-64$.

Neary, J. P. (1978) Dynamic Stability and the Theory of Factor Market Distortions. American Economic Review 68, 672-82.

Neary, J. P. (1981) On the Harris-Todaro Model with Intersectoral Capital Mobility. Economica 48, 219-34.

Panagariya, A., and P. Succar (1986) The Harris-Todaro Model and Economies of Scale. Southern Economic Journal 52, 986-998.

Partridge, M. D., and D. S. Rickman (1997) Has the Wage-curve Nullified the Harris-Todaro Model? Further US Evidence. Economics Letters 54. $277-$ 282.

Portes, A., et al. (eds.) (1989) The Informal Economy: Studies in Advanced and Less Developed Countries. Baltimore: The Johns Hopkins University Press.

Quibria, M. G. (1988) The Harris-Todaro Model, Trade Unions and the Informal Sector: A Note on Calvo. International Economic Review 29, 557-63.

Rauch, J. (1991) Modeling the Informal Sector Formally. Journal of Development Economics 35, 33-47.

Rauch, J. (1993) Economic Development, Urban Underemployment and Income Inequality. Canadian Journal of Economics 26, 901-918.

Sato, Y. (2004) Migration, Frictional Unemployment, and Welfare-improving Labour Policies. Journal of Regional Science 44, 773-793.

Sen P., A. Ghosh, and A. Barman (1997) The Possibility of Welfare Gains with Capital Inflows in a Small Tariff-ridden Economy. Economica 64, 345-352.

Srinivasan, T. N., and J. Bhagwati (1975) Alternative Policy Rankings in a Large Open Economy with Sector-specific Minimum Wages. Journal of Economic Theory 11, 356-71. 
Srinivasan, T. N., and J. Bhagwati (1978) Shadow Prices for Project Selection in the Presences of Distortions: Effective Rates of Protection and Domestic Resource Costs. Journal of Political Economy 86, 91-116.

Stiglitz, J. E. (1974) Alternative Theories of Wage Determination and Unemployment in LDC's: The Labourturnover Model. Quarterly Journal of Economics 88, 194-227.

Stiglitz, J. E. (1976) The Efficiency Wage Hypothesis, Surplus Labor, and the Distribution of Income in the LDCs. Oxford Economic Papers 28, 185-207.

Stiglitz, J. E. (1977) Some Further Remarks on Cost-benefit Analysis. In H. Schwartz and R. Berney (eds.) Project Evaluation. Washington, D. C.: InterAmerican Development Bank.

Stiglitz, J. E. (1982) The Structure of Labour Markets and Shadow Prices in LDCs. In R. H. Sabot (ed.) Migration and the Labour Market in Developing Countries. Boulder: Westview Press.

Todaro, M. P. (1968) An Analysis of Industrialisation: Employment and Unemployment in LDCs. Yale Economic Essays 8, 329-492.

Todaro, M. P. (1969) A Model of Labour Migration and Urban Unemployment in Less Developed Countries. American Economic Review 59, 138-48.

Suits, D. B. (1985) US Farm Migration: An Application of the Harris-Todaro Model. Economic Development and Cultural Change 34, 815-828.

Yabuuchi S., and H. Beladi (2001) Urban Unemployment, Informal Sector and Development Policies. Journal of Economics 74, 301-314.

Yabuuchi, S., H. Beladi, and G. Wei (2005) Foreign Investment, Urban Unemployment, and Informal Sector. Journal of Economic Integration 20, 123138. 